\title{
The Trisected Society: Welfare Reform in Early Victorian Fiction
}

Although the subject has long been concerned with culture it is only fairly recently that social policy has begun to formulate the many connections systematically (Baldock, 1999). This development is perhaps due to the relative robustness of advanced welfare states in the face of assaults firstly by radical conservatism and then by the supposed forces of globalisation. State welfare has proved to be less vulnerable than its supporters feared or its detractors hoped it would be. Initial analysis attributed this to some kind of policy lag or institutional inertia, e.g. to resistance effected by public sector producers or powerful electoral constituencies (Myles \& Pierson, 2001). But these arguments tended to treat preferences and interests as given, it not being clear why actors hold the views that they do or why some can mobilise more effectively than others. 'Path dependency' accounts have therefore risked being as deterministic as the apologists for TINA (there-is-noalternative) they were designed to oppose. Some researchers have therefore turned to culture as a further means of explaining contemporary trends (Clarke, 2004: Ch2).

This article is not a contribution to this debate, not directly anyway. It is instead the first stage in a long-term project designed to elucidate the role that popular culture has played in the evolution of British social policy. Histories of popular culture make, at best, only passing reference to social policies (e.g. Rose, 2001), while histories of the latter tend to use popular culture as a way of illustrating social changes rather than as influential historical documents in their own right (e.g. Fraser, 2003). The premise of this project is that we achieve only a partial understanding of popular culture and social policy unless we are prepared to relate the two more closely, that each is an important engine for the other; its ultimate objective is to throw new light on British identity and so offer a broader understanding of recent welfare developments.

The following article focuses upon some seminal novels of the 1840 s and $1850 \mathrm{~s}$ in their relation to social policies of the early Victorian period - centring upon, but not limited to, key legislative changes. The books are Oliver Twist (1838), Hard Times (1854) and Little Dorrit (1857) by Charles Dickens; Coningsby (1844) and Sybil (1845) by Benjamin Disraeli; Mary Barton (1848) and North and South (1855) by Elizabeth Gaskell; Yeast (1848) and Alton Locke (1850) by Charles Kingsley. ${ }^{1}$ These 'social problem novels' have been of interest to literary critics since the 1950s and the first aim of this article is to relate them to key social policy debates that most literary critics have avoided. Its second and more ambitious aim is to infer from the above novels a certain discourse that challenged some aspects of classical political economics while enabling others to be consolidated. In what follows I will infer from these novels a particular view of society and an accompanying set of precepts for the ethical recoordination of industrial society.

First, some disclaimers. There are two questions I am not going to address in this article, although they will certainly need to be by the later stages of the project. Hhow should we model the relationship between culture, socio-cultural studies and social policy? Should the history of social policy be conceived as the unfolding of an essence (whether as a liberal humanist story of progress or a quasi-Marxist one of social control) or as a Foucauldian narrative of non-essentialist subjectivity? Because these questions each require an article of their own, and because a full account depends upon a prior understanding of popular culture and welfare history as they

\footnotetext{
${ }^{1}$ These are not the most popular books of the time but are those seen as the most socially significant in retrospect. See the following argument about 'selective tradition'. And note that other novels by Dickens will be drawn upon whenever appropriate.
} 
have connected at specific conjunctures, I am placing them in brackets and to one side here. [And note that since this has been written for a social policy audience I will be assuming a basic knowledge of the history of the period.]

\section{Cultural Materialism and New Historicism}

What cannot be avoided is an understanding of the main responses made to social problem novels by those working at the boundaries of literary criticism and social history. There have been three main schools: cultural materialism, new historicism and feminism; below I critique the first two and, throughout the article, draw upon feminist contributions more generically.

For Raymond Williams (1958: Ch.5; 1961: Ch.2) culture should be understood as socially and ideologically engaged, and vice versa. Literary forms should neither be detached from their material environment (as 'new critics' had proposed) nor treated as superstructural reflections of an historical essence (as crude Marxists had supposed). The 'structure of feeling' was Williams's term for how ideology is an experience lived through cognition, emotion and body. So what the 'industrial novelists' were doing was articulating and disseminating a particular structure of feeling: one that legitimated the fact of industrialism while allowing readers to assuage their guilt cathartically at its social damages by feeling an escapist sympathy towards its victims. Dickens et al therefore offer the middle class an escape route from the horrors of industrialism while failing to imagine alternative social realities.

Williams's approach is echoed in that of Kettle (1958), Lucas $(1966,1977)$ and Smith (1980). For instance, Smith regrets that in feeling a genuine horror at urban squalor and social deprivation the early Victorian novelists were not able to think beyond this reaction and, instead, were content to do no more than invite the same emotions in their readers. Disgust and pity thereby remained unconverted into political forms of mobilisation as the universal claims of the poor are neglected.

Yet by the late 1970s some were seeking new types of historical interpretation. Where cultural materialists read the past largely (if not entirely) through the lens of the present the new historicists sought to understand what the Victorian novelists did, as opposed to what contemporary critics think they should have done. For Gallagher (1985) social problem fiction was a site through which complex cultural energies can be seen to flow. Rather than latch onto some of these as real and others as illusory (allowing novels to be judged as either successes or failures) the job of the critic is to trace those discourses across a wider social field than that of fiction alone. If novels do not offer a programme of reform that is because their actual purpose is to give aesthetic space to the fragmented discourses of industrial social change.

Other new historicists, however, have avoided Gallagher's Foucauldian poststructuralism, accusing it of lacking in critical discrimination. According to Poovey (1995) social problem novels represented a welcome attempt to feminise debates hitherto dominated by a masculinist concern with statistical abstraction and social engineering. The novelists therefore view society through a regendering of knowledge and identity even while upholding traditional codes of male/female attitude and behaviour. Poovey therefore agrees with feminist critics that gender is both present and absent in Victorian fiction (Ingham, 1996). Guy (1996), too, has been inspired by the new historicism while trying to understand how and why Victorian novelists acted upon their environment. She says that while they could recognise 'problems in society' the theoretical equipment needed to perceive social problems (and origins and solutions) was not yet available. It is not that they 
consciously rejected a sociological approach, more that such an approach barely registered in the individualistic paradigm within which they were forced to work.

So where cultural materialism regards Victorian novelists as the spokespeople of the middle-class, sourcing their aesthetic failures to the structural contradictions of the early nineteenth century's socio-economy, new historicists are less judgemental and concerned to identify complexities, where any flaws in the novels reflect the impossibility of reconciling the multifaceted discourses circulating around the social body (Brannigan, 1998). So new historicism is concerned with historical context rather than political interpretation, arguably allowing it a greater freedom of movement and wider frame of reference than ideological critiques.

The strength of new historicism is that it opens our eyes to factors that go far beyond class per se. The potential problem is that it neglects the extent to which social problem novelists were making conscious and so political responses to the age whose zeitgeist they were also articulating. Take one example. Guy observes that we ought not to judge these novelists harshly because we should not expect them to have seen at the time what we can see in retrospect. Yet how certain can we be sure that they did not? If it is difficult (and arguably impossible) for us to transplant ourselves into their interpretative horizons, if we can only ever gain an incomplete and hazy understanding of their understanding, then perhaps an over-generous reading is as simplistic as an over-harsh one. Indeed, perhaps it is the cultural materialists who are being scrupulously honest about this.

To the extent that they read the past through the present they are indeed wrong if tempted to be too dismissive of social problem novelists (but see Williams, 1983: 155). Yet even here Guy underestimates the extent to which they consciously rejected sociological, i.e. non-individualist, alternatives to political economics (Smith, 1980: 181-9). In Mary Barton unions are presented as understandable but regrettable responses to urban industrial deprivation, the labourer's equivalent to employers' intransigence that threatens to undermine the possibility of worker and boss recognising their co-dependency. Trade unions are depicted as socially destructive militants and Chartism as naïve; instead, workers should form a communal bond with like-minded employers. The journey of John Barton from good neighbour to murderer to penitent eclipses any possibility of a midway alternative in which labour organisations are oppositional yet non-revolutionary. A similar trick appears in Hard Times where union members lack the personal integrity of Stephen Blackpool and the strikers are as self-deceiving as Bounderby (David, 2001: 89). ${ }^{2}$ And in Yeast Christian fellowship is depicted as the only alternative to anarchy and Tregarva's ambition is to become a gentleman and so a more effective spokesman for the poor rather than for one class against another. Therefore, while these novelists did not have access to systematic alternatives to laissez faire economics they were certainly aware of, and chose to close off the imaginative spaces for, movements more radically political than themselves. If they were immersed within an individualistic paradigm it is partly because they chose to reside there.

But where cultural materialism evades the new historicist critique entirely is in its willingness to read the present through the past. Here, the aim is not to contextualise Victorian fiction but to use Victorian fiction as a means of contextualising ourselves. This is what Williams (1961: 49-53) refers to as a 'selective tradition'. In order to understand the lived culture of a period because we cannot absorb every document we

\footnotetext{
${ }^{2}$ Dickens seems to have sympathised with workers' desire to strike while regarding the act of going on strike as an 'honest mistake' impelled by irresponsible agitators and employers (Ackroyd, 1990: 7268).
} 
inevitably make selections according to what is seen in retrospect as important. Interpretation therefore has to be conscious and, if so, then the political agenda of the interpreter cannot be suppressed by the avoidance of judgement. This means that the failures to which cultural materialists draw attention are less the failures of certain novels and more the failures of a contemporary culture that underestimates the driving force of material factors (cf. Eagleton, 2004: Ch.7). So even if transhistorical and transcultural forms of knowledge are unobtainable (Gallagher \& Greenblatt, 2000: 5666) this objection misses what cultural materialism is really trying to do: identify the ideological strategies by which a situated social order is both changed and maintained across time (Sinfield, 1992: 39-41).

Both schools therefore 'read through' social problem novels, being sensitive to their differences but treating them as portals that express, partly consciously and unconsciously, the spirit of the period. Cultural materialism has a slight advantage in its refusal to abandon ideological critique in the fashionable rush towards discourse analysis. Accordingly, I am here distinguishing between hegemonic and counterhegemonic cultures. The former encompasses a complex of dominant values, norms, codes, representations and 'common sense' understandings; dominance implies here not a hierarchy of control but what, over a given period, might be identified as the most influential coordinates through which social practices and assumptions are framed. Counter-hegemonic cultures are therefore those which recoordinate the prevailing maps, whether through conscious resistance or otherwise, by imagining and seeking to realise alternative histories, presents and futures. New historicism is crucial as a reminder that these cultures are multiple, diverse, ambiguous, fuzzy and indistinct. So in what follows I will propose that Dickens et al be read as both hegemonic and counter-hegemonic authors, an interpretative shape made possible through our knowledge of succeeding welfare history and the evolution of their cultural interventions (though I will say little about these here).

Cultural materialists are arguably more sensitive to the political implications of historical and literary interpretation. Our conception of what I referred to metaphorically as the picture and its pixels is always a matter of ideological interpretation and, because subject to revision, struggle. This is what Williams (1961: 49-53) refers to as a 'selective tradition'. Because, in order to understand the lived culture of a period, we cannot absorb every document we inevitably make selections that while striving for objectivity are inevitably shaped by contemporary agendas. Interpretation therefore has to be conscious and, if so, then the political agenda of the interpreter cannot be suppressed in the search for 'social energies'. So although new historicists are correct to observe that politics means more than ideology (****) they are far too quick to abandon ideology itself. For even if transhistorical and transcultural forms of knowledge are unobtainable (Gallagher \& Greenblatt, 2000: 56-66) this objection misses what cultural materialism is really trying to do: identify the strategies by which a situated social order is both changed and maintained across time (Sinfield, 1992: 39-41). This means that the failures to which cultural materialists draw attention are partially the failures of certain novels and partially the failures of a contemporary culture that underestimates the driving force of material factors (cf. Eagleton, 2004: Ch.7).

\section{The Rise of Political Economy}


We therefore need to appreciate the hegemony that social problem novels both countered and contributed to.

[ignore romanticism and idealism (for most part)]

[moral economy]

The essence of political economy has already been alluded to. It was largely of Utilitarian inspiration that rejected abstract conceptions of self and society, seeing people as driven by animal-like instincts. If, as David Hume had contended, reason takes its lead from the passions then how can the passions be contained and channelled in ways conducive to social harmony? For Hume the answer involved erecting a system of government that encouraged persons to see outside of themselves and converted their sentiments and cultural ties into forms of publicly oriented benevolence. Others gave a more pessimistic response. For Mandeville all action consists of egoistic self-interest that may be coordinated as a 'happy accident' to ensure public goods but we should not imagine that people can act with benevolence. It was Adam Smith who converged these two approaches. People can be made virtuous but because egoism is the spring of human motivation there is a need both to confine egoism through the rule of law and harness it via free market relations. Since supply and demand always tend to equilibrium then buyers and sellers will gain by acting in their self-interest and what Mandeville had imagined as a happy accident was nothing more than an invisible hand that unintentionally converted private interest into public welfare. At the heart of political economy therefore lies a vision of homo economicus, perhaps capable of being schooled in the virtues but nevertheless rife with selfish instincts that must be routed through laissez faire markets into public goods.

Bentham's contribution was to propose that while private property and free exchange are vital, certain types of deliberate social intervention are needed to build further bridges between private action and public welfare. Those bridges are the ones which permit the total amount of utility in society to be raised. Since humans are governed psychologically by two 'sovereign masters' - the pursuit of pleasure and the avoidance of pain - then economic, political, legal and social rules must be shaped to maximize the rewards for obedience to them and the penalties for disobedience. The environment required for homo economicus to thrive consists not only of free markets but of socially engineered institutions.

Subsequent contributions had the effect of highlighting some aspects of Smith's and Bentham's thinking, while consigning others to the shadows. Most pessimistic of all was Malthus's contention that while psychological egoism was one thing sexual egoism was of an entirely different order. Sharing with the rest of nature the impulse to reproduce human population growth was exponential and so bound to outstrip the supply and production of food. War, famine, disease and poverty were therefore inescapable aspects of human fate. However, Malthus was not immune to Benthamism and later refined his hypothesis to allow for the possibility of reducing the birth rate through moral restraint (sexual abstinence), social discipline (letting the labouring classes pay the price for their permissiveness) and birth control techniques. Ricardo's prognosis was also pessimistic. With rising population the rental value of land would rise and, contra Smith, allow power and wealth to amass in the hands of the unproductive landlord rather than the productive capitalist. But here, too, fears of unsupportable population growth were unfounded, as were the assumptions that capitalist industry would remain subordinate to the landowners and that profits would 
be squeezed by wages. Finally, James Mill represented the scientific application of Utilitarianism. Since intelligence is as much acquired as it is inherited the key to social progress lay in improving the system and content of education. Ironically, the regime of instruction which Mill then imposed upon his son was to contribute to the eventual demise of early nineteenth century political economy.

By the 1820s, then, the principles of political economy were in place and being fitted to the changing structures of inequality. The household 'oeconomy' was being hollowed out and replaced by formal economies governed by detached, contractual and interchangeable relationships. Homo economicus is central, an atomistic figure driven by self-interest in perpetual collision with the self-interest of others. Family, class and nation provided some orientation but no longer to the extent that they alone could guarantee social integration. This necessitated not only economic freedom the incentives of competition and profit that the price mechanism provided - but also moral instruction and social discipline. Supply and demand would always balance and markets always clear if you left them alone. So where Bentham had assessed social reform against the principle of utility, such calculation gradually fell away so that social reform was useful in so far as it augmented the market as an end in itself wealth became not a potential instrument of utility but utility per se. Regulation was necessary if and only if it advanced the wider cause of deregulation. This meant that where abolishing the Corn Laws was good and trade unionism bad, regulating the habits and attitudes of the poor was equally worthwhile since this too served the same objective: the production of wealth. Instruction and discipline must be directed more towards the residuum, those who could not control their appetites unassisted and so threatened to usurp free market forces, private property rights and good governance.

So while Smith and Bentham reigned as mentors their intellectual descendants derived more from the materialistic and mechanistic elements of their thinking, allowing the earlier Humean focus upon empathy and public benevolence to fade. For if the social good could be facilitated through impersonal rules and systems of coordination then why bother with human sympathies given their complexity and disorderliness? Dickens et al therefore have to be understood not simply as reacting against the severities of political economy but as archaeologists of an older tradition that recent political economy had occluded; less as philosophers than as intuitive artists capable, as the romantic poets before them, of hearing and translating distant sounds to which others were deaf.

\section{A Brief History}

What follows is meant to be neither comprehensive nor definitive, merely an extrapolation of those events and movements most pertinent to this article's analysis.

In 1833 and 1835 Alexis de Tocqueville made two brief visits to England (Drescher, 1964). ${ }^{3}$ Driven by reports that the country might be headed towards revolution Tocqueville wanted to directly observe in England the kind of pre-revolutionary conditions that had occurred in those countries, America and France, he felt typified the modern age. Like many before and after Tocqueville witnessed the extreme poverty and deprivation skulking through urban sprawls like Manchester. He concluded that the avoidance of revolution would depend upon whether England addressed the impoverishment of the poor and upon its success in negotiating the social hazards of a transition to democracy. Yet Tocqueville also anticipated that

\footnotetext{
${ }^{3}$ Drescher, S. (1964) Tocqueville and England, Cambridge.
} 
revolution was extremely unlikely. For while in Europe the middle-classes sometimes attacked privilege per se in England they usually preferred to become privileged; in Europe the middle and working classes were more likely to make common cause against aristocratic rule, while in England most of the middle class wished to transfer the crown to their heads and raise the drawbridge on those less fortunate who were following on behind.

A few years later, in 1842, Friedrich Engels (1969) visited London and Manchester for the first time. He, too, was appalled by what he found and yet also excited by the possibilities for radical social change that industrialised suffering presented. During his journeys through streets and labyrinths riddled with disease, crowding, starvation and death Engels suspected that the causes for such deprivation could be found in the exploitations committed by the propertied against the propertyless. In addition to the surrounding urban darkness there was lurking within those streets a revolutionary energy that the apathy and hopelessness induced by poverty could not contain forever. An English revolution, he was certain, could be expected in 1852 or 1853.

Why was Tocqueville so right and Engels so wrong? To some extent it was luck: Engels arrived at the start of the 'hungry Forties' when recession had hit and political agitation was at its height. Yet there is something more. Tocqueville possessed more of a journalist's and novelist's eye and so perhaps sensed cultural and national nuances that a sociologist and philosopher like Engels missed (Lucas, 1977: 54-5). To a large extent those nuances concern the composition of the classes: whereas Engels extrapolated what he saw into historically-significant blocs, Tocqueville's was alert to the gradations and subtleties that absorbed and sublimated the great socioeconomic forces that travelled through and around them. This meant that Tocqueville could see within the classes those factors that would dissipate any revolutionary energy: the communal solidarities, familial securities, psychological horizons and competitive enmities that would propel British society in other directions.

The political and economic reforms of the 1830s and 1840s therefore have to be read as a series of shifting coalitions between the classes that were ultimately most successful in realising the aspirations of the industrial bourgeoisie. The 1832 Reform Act was largely an attempt by Whigs to pre-empt more extreme measures that, by extending the franchise by half a million voters and chipping away at political corruption, also attracted support from democrats and radicals who hoped that more upheavals would indeed be forthcoming. If large sections of the Lords and landowning aristocracy were outraged by this assault on their privileges the assault was muted compared to the recent 1830 French revolution and so recognised as designed to preserve rather than demolish; and if progressives were enthused the Act stopped far short of universal suffrage by granting the vote only to men owning property worth at least $£ 10$. In short, the 'new Whigs' (a coalition of aristocrats and middle class reformers) had initiated another of those very British revolutions in which seismic activity is circumvented, the redistribution of privilege that Tocqueville had identified. The 1834 Poor Law was more about continuity than disruption.

While John Kay's 1832 report into the Manchester cotton industry was the first of many that exposed urban overcrowding and disease unimaginable to any who had not witnessed it, he also talked of a moral degeneracy that reassured the non-poor of their lack of culpability. The Poor Law Report of 1834, too, was concerned with the 'rewards' for indolence and vice. Inspired by Bentham's portrait of individuals as economic rationalists who seek pleasure and the avoidance of pain Edwin Chadwick formulated the principle of less eligibility, the idea that relief must always be provided 
at a level less than that of the lowest paid work. The principle would therefore be a means of separating the deserving from the undeserving, with the workhouse reserved for the latter. Since by now the Speenhamland System retained few defenders, as it both drained parish resources and allowed employers to avoid their responsibilities, some working class leaders supported the new reform. On its enactment, though, anti-Poor Law protests quickly spread with riots in several industrial towns breaking out in 1837 (Longmate, 2003).

By 1838 the Chartist movement had therefore been born. Demanding universal (male) suffrage and an end to property qualifications Chartism was not unconcerned with social conditions but believed that achieving some measure of political equality was the sine qua non of social reform. It therefore represented a new coalition between middle and working class democrats, radicals and socialists that opposed the compromise Whigs had made with the established order. As economic recession bit the Chartists pursued the twin strategies of facilitating insurrection while lobbying parliament with marches and petitions - the 1842 petition contained 3 million names. With increasing prosperity, though, the flames of Chartism flickered away. The populace seemed able to gain both from the free trade advocated by the mill owners (after the 1846 repeal of the Corn Laws the price of bread fell) and the factory regulation that conservatives supported as a counter-attack against the bourgeoisie. Chartism revived with the 1847-48 downturn but quickly died off again, though not without clearing a way for the next generation of trade union reformers.

What this movement would face was a liberal-Tory political class that knew how and when to reform through piecemeal concessions, and a working population that was happy to avoid revolutionary excesses. By 1853 a series of Factory Acts had restricted the (official) working day to 10 and a half hours and public health measures advanced the cause of sanitation - with qualified success. In attempting to promote social reform workers' representatives would attempt to play liberals and Tories off against the other, in order to make cross-class coalitions work in their favour, and continue to highlight social conditions wherever (and it was often) the reality of reform did not correspond to the rhetoric. It was in this latter respect that the novels of Dickens, Gaskell, Disraeli and Kingsley were useful in pricking the British conscience and urging it forward. Yet the 1850 s also experienced the start of midVictorian prosperity and the widespread feeling that intervention was generally unnecessary since piecemeal reforms appeared incrementally effective and all decks would benefit as the tides of economic depression receded. Dickens et al would therefore appeal to a social conscience that was to some degree already satiated and it is in this context that their interventions should be understood.

\section{Reacting to Welfare}

I have sketched a history in which upheavals are understood as relatively modest and absorbable by the prevailing order. Although it did not appear so at the time the period was one of continuity rather than crisis. Policy reforms flowed in the direction of prevailing social currents, e.g. sanitation reform was propelled as much by middle class fears as by concern for deprived areas $(* * * *)$. If Britain therefore avoided the turmoil that characterised most other European countries at this time (and throughout the century) why was this? The answer proposed by many $(* * * *)$ is that it was due to processes of specific cultural hegemonisation and I want here to illustrate what this involved by examining the social problem novels listed above and extracting from them a discourse of welfare that all appear to share. In order to do so it is first useful 
to review what they actually said about recent developments - though only a few examples can be cited for reasons of space.

First, their dismay at contemporary poverty is obvious as is their sense that poverty is partially, if not entirely, manmade. This explains why they frequently resorted to the populist mechanism of the day - sentimentality and melodrama - in order to shock and guilt their audience into action. Lenard (1999: 46) is correct to observe that sentiment in the early Victorian novel was not so much a replacement for politics as its extension, a way of overcoming physical and symbolic distance by making middleclass readers weep for characters in the hope that they will go on to weep for their real-world equivalents. Novelists certainly portrayed the lack of material things but knew that readers respond principally to the human consequences of this lack. Statistical surveys achieved, and still achieve, less than a good, socially conscious drama. Yet the danger of sentiment is in its potential for political obtuseness. The more subjects are foregrounded the more likely are their structural and institutional contexts to be obscured. In responding to characters we may easily adopt the very pathologism which was the source of their plight in the first place, a paradox with which Dickens came to wrestle (see below).

Second, they sought to place a large question mark over the assumption that political economics provided the answer to poverty. Nussbaum (1995: 20-5) detects in Hard Times an hostility to particular kinds of policy-making and public reasoning. Qualitative diversity is regarded as superior to quantitative abstraction since the latter eclipses the human dimension without which institutions are rendered ridiculous. Gradgrind's school is little more than a calculator in which the children are reduced to machine parts. Regret is therefore expressed by Dickens at the loss of subjectivity in the drive to aggregate the total utility of groups and collectivities. Autonomy is the freedom to acknowledge necessary truths that have already been discovered by others. Hard Times laments the belief that the accumulation of data and the arithmetical manipulation of statistics is sufficient to generate solutions to human problems and a philosophy of self-interest is contrasted with emotions and motivations that Dickens regards as important: not only love, empathy and altruism but the sense of wonder and mystery that Gradgrind disdains because it cannot be counted. In opposition to the above Dickens presents the circus, not a model of an alternative social system but a metaphorical exploration of what happens when we leave systems behind and embrace spontaneity, fun, absurdity and attachment to the immediate. Of course, while challenging the political economists Dickens may also be articulating another kind of conservatism since some aspects of the above may be needed for the radical politics that Dickens rejected, e.g. trade unions are as alien to the circus as utilitarians.

Third, their hostility to the workhouse is clear. Oliver's request for more food is rightly taken by the Board of Guardians as a challenge to their very existence. In asking for more than dietary science had determined was necessary for daily sustenance Oliver not only lacks the required self-discipline but is questioning the philosophy of less eligibility and so of self-help. He is now not only a member of the undeserving poor but a rebel who, being beyond help, must now be apprenticed out. The subversiveness of the episode comes in the difference between what the Board and the reader knows. Oliver is flogged as a warning to the other boys not to follow his example, yet Oliver had already been acting as a (probably reluctant) spokesman for the others. If he is beyond help then so are they and the entire rationale of separating families and confining children to the workhouse collapses. Those contemporary critics who complained that Dickens had ignored the advantages of the new Poor Law over the old were missing the point, then: his target is not a specific 
institution but the hypocrisy of a society that proclaims the virtues of self-interest for everyone except those who were its greatest victims. The irony is that decent society is most at threat from criminals like Fagin who mimic its ethic of self-interest.

Fourth, there is only modest support for democratisation of the state. In Coningsby Disraeli attacks the new Poor Law for further undermining the parochial order of a nation in which the privileged had once given thanks for their position by taking responsibility for the peasantry (noblesse oblige). In Sybil the spokesman for the workhouse, Lord Marney, is later stoned to death by the mob violence his views are held to have unleashed. So, for Disraeli, since the working class can and should be represented by enlightened members of the aristocracy there is no need for universal suffrage or for workers' representatives in parliament. Dickens offers a pessimistic and near anarchistic view in which the many labyrinths of the state wrap around themselves in a Kafkaesque loss of authority, effectiveness and purpose. That the state is capable of being both efficacious and progressive is something Dickens can barely countenance. Although he supported the Second Reform Bill his hostility to organised labour may be due to a fear that this would make working people complicit in the activities of the governing classes he disdained.

Fifth, they were also against contemporary forms of education. Most famously, Dickens's savage portrayal of Dotheboys Hall seems to have been no exaggeration and led to the virtual extinction of the Yorkshire boarding schools upon which it was based. In Hard Times he turns his fire of the kind of cold, mechanical education that he feared utilitarianism engendered and in Our Mutual Friend his humour is directed at the belief that meaningful social mobility can be achieved through education alone. Yet it is not clear what, if anything, they propose as an alternative. Kingsley's heroes are autodidacts guided by mentors; Disraeli's are either privileged aristocrats who have acquired a sense of their responsibilities beyond school, or workers' representatives who have accumulated learning from a handful of books; Gaskell looks to education in the Christian virtues first and foremost.

Sixth, their response to issues of disease and sanitation is more precise. When in Yeast and Alton Locke characters die from diseases contracted from social conditions they had ignored the implication is that poor public health is not something from which the rich can escape and their neglect will be revisited upon them. It is here that our novelists most clearly articulate a post-individualist message. In Bleak House Esther contracts smallpox from Jo, a figure who seems to carry the darkness and squalor of Tom-all-alone's around with him. It is here that our novelists were most obviously in favour of government intervention though parliament's inertia here confirmed why a cynical view of it was appropriate (Ackroyd, 1990: 746).

Seventh, the work ethic is valued and so idleness deplored as wasteful of human talent and a potential source of social disruption. In Gaskell's novels both employer and employee are damned when they ignore the work ethic of the other: in Mary Barton the extremism of Carson and Barton propels both towards tragedy while in North and South Thornton perceives Higgins as trustworthy once the latter's dedication to work has become clear. Alternative ways of organising the labour market are not proposed but, as already indicated, Chartism and trade unionism are regarded as symptoms of economic malaise rather than as possible solutions. Therefore, the political economist's argument that the market cannot be bucked remains unchallenged. What the social problem novelists argue is that the burdens and benefits be more fairly distributed (as is clear from the responses of Sissy Jupe to her economics lesson) and that opportunities for upward mobility be expanded so that men (sic) may developing their faculties (as in Tregarva's desire to become a 
gentleman or when, in Sybil, the former militant, Devilsdust, becomes a capitalist). Scrooge's redemption leads him to higher wages to Bob Cratchit but the nature of the wage contract, and so of market relations, remains the same.

Finally, our novelists were cautious on the subject of charity, philanthropy and the early examples of social work. While Kingsley does not query charitable motives he does seem to condemn it as a palliative rather than a preventative, something inferior to Tregarva's instinctive attempt to save the dog of the well-to-do women he loves or Colonel Bracebridge saving the life of Tregarva in turn. Dickens goes further still in condemning certain types of charitable motivation, e.g. in the near-misogynist depiction of Mrs Jellyby (see below). Gaskell comes closest to defending charity as an expression of Christian humanitarianism. The famous scene when Barton and Wilson go to great lengths to help the Davenports communicates a strength of feeling greater than attachment to one's self-interest; and in North and South visits between households are a means by which social discourse can proceed, but only once based upon a sense of mutual respect and recognition. What each novelist seems to be opposing is the misplaced use of charity as a response to social squalor. Charitable actions that patronise, moralise or stigmatise are rejected in favour of spontaneous affection and a human instinct to assist others.

It is therefore not too difficult to spot in the early Victorian novelists an agenda similar to the five giants later identified by Beveridge: want and poverty, ignorance and education, disease and sanitation, work and idleness, charity and squalor. The question is from what kind of discourse did these concerns derive and what does this tell us about early Victorian conceptions of welfare and social policy?

\section{The Trisected Society}

[society then ethics]

\section{Class}

I have already outlined the suspicion these novels bear towards trade unions, the point being that because class divisions were seen as the essential to social problems anything which exacerbated such divisions could not be thought of as contributing to the solution. North and South offers the most sympathetic and sophisticated portrayed of organised labour. The book concludes with Thornton describing his conversion to a new form of industrial relations based upon worker consultation and participation which while not preventing strikes would render them less hostile and destructive; Higgins, meanwhile, shares with his colleagues a recognition of employers' and employees' common humanity. Institutional reform is therefore not ruled out but considered by Gaskell as ineffective unless based upon personal discourse, mutual charity and sympathy. Yet Gaskell's emphasis is still upon morals and so what I will call the 'principle of equivalence'. Higgins had earlier accepted Margaret's view that unionism had been responsible for Boucher's militancy and later suicide when, in attacking the closed shop, there is an implicit comparison between compulsion exercised by employers and that exercised by workers. Compulsion by labour is seen to exacerbate the broader injustice propagated by capital: it is denoted as a sin born from the masters' sinning, another form of false materialism that diverts us from matters of religion and morality. Margaret applauds the solidarity of labour movements but only if it embodies the ethos of a Christian community. Therefore while she rejects some arguments from equivalence, e.g. that capital and labour are at 
equal risk from an industrial downturn, Gaskell depicts both sides as having to travel a similar spiritual and moral distance to achieve the interaction that, by the end of the novel, offers at least some kind of hope. Cooperation involves the class meeting in the middle and is not advanced as an alternative form of economic relation to competition.

Class is also occluded as a social solution by an appeal to family, Christianity and nation. We will explore family shortly and so deal only with the latter two here.

It is clear that Kingsley believes class politics to be subordinate to Christianity. In Yeast revolution is represented as a possibility - however undesirable - if the affluent do not attend to social conditions. Kingsley goes further than other authors in condemning charity (though not its motivation) as a palliative rather than a preventative and calls for a social economy that enables men (sic) to develop their faculties. Property diverts those who own it from a proper recognition of what it is to be virtuous; selfishness cannot unite people. However, the socialistic aspects of this view are as tyrannous as a competitive economy unless anchored firmly in an ethos of Christian community and fellowship. This is made clear in Alton Locke where Chartism receives its most hostile condemnation precisely because, of our authors, Kingsley was most sympathetic to it. Locke's well-meaning intervention sparks a riot, as the appetites of the destitute risk being unleashed beyond physical hunger by the irresponsibility of political radicals, and he comes to accept the words of Eleanor:

Denounce the effete idol of property-qualification, not because it happens to strengthen class interests against you, but because...there is no real rank, no real power, but worth; and worth consists not in property, but in the grace of God. (Kinsgley, 1905: 358)

Christian Socialism is an ethos of mutual sacrifice, the final realisation of the kingdom on God on earth.

Finally, Disraeli performs the same trick by appealing to national history and destiny. In Coningsby he defends an aristocratic paternalism where authority and labour recognise their duties to one another, the ultimate authority being the Crown and his/her ascendancy beyond class. Unless commanded by national pride human passions will mould other, less benign divinities (Disraeli, 1968: 251-4). In Sybil this is proposed as the only viable solution to the 'two nations' of rich and poor. Yet with few exceptions Disraeli fails to depict these two nations since their protagonists share practically the same vocabulary, customs, sympathies and interests. Far from existing on opposing sides of an unbridgeable gulf they are already one nation whose mutual comprehension has been forgotten. The union of Sybil and Egremont symbolises the act of recollection which needs to be performed by creating a paternalistic hierarchy that, as in Trafford's factory, attends to the moral and material health of the people. Trade unions are practically depicted as branch of the freemasons and Chartism as an ineffectual barrier against the forces of revolutionary violence that it stirs into motion (Disraeli, 1981: 219-21, 417).

Our early Victorian novelists therefore recognise class as a problem but will not admit class analysis or politics as part of the solution. Despite the actual moderation of Chartism, class conflict invariably, and quickly, descends into violence and attempted revolution. This suggests what is perhaps the central contradiction in their social visions: the weight of circumstance upon human affairs is simultaneously affirmed and denied. Returning to Hard Times Webb (1981: 94-9) highlights Dickens's awareness of environment in determining the novel's characters but when 
presenting the normative issues (the question of how Coketown should be governed) this awareness is suppressed and circumstance fades, e.g. as in Gradgrind's facile conversion. So in contrast to Gaskell et al Dickens's solutions to social problems appear more trite precisely because he is more aware than they of the weight of environmental constraints. Like Kingsley's, Dickens's early characters often float free of their social backgrounds, e.g. Oliver's manner and speech do not derive from his upbringing but seem to be biological inheritances, but he would later tie self and environment together more closely so that the happy endings, e.g. in Great Expectations, become more incongruous as the overall vision becomes more pessimistic. Yet this alternating triteness and pessimism is the cul-de-sac into which Dickens drove himself by ruling out the possibility of social solutions to social problems through a politics of collective action. His sense of the interdependency and complexity of human affairs also led him to rule out systematic intervention; in Bleak House the fog both unites and obscures the many sectors of society and, whether the narrator is Dickens or Esther, is not something from which we can ever entirely escape.

Dickens therefore represents an extreme example of the juxtaposition of circumstance and non-circumstance. The conflict here is reconciled by allowing the determining influence of material circumstance to fade and be overtaken by other factors. The possibility and desirability of economic and institutional reform through collective action therefore fades also. This would not be a contradiction if, like the political economists, they attributed deprivation to moral failings only. But while they attribute importance to moral (and immoral) behaviour Dickens etc do not have recourse to this exit strategy since they stress time and again how the poor are also victims of circumstances beyond their control. Social problem novels therefore embody a contradiction that may well articulate a contradiction of their age: a recognition of material circumstance combined with an hostility to materialist and collectivist solutions.

\section{Work}

So although they express horror at the workhouse they revise rather than reject the deserving/undeserving distinction upon which it was based. Whereas the political economists focus upon ability and willingness - where a disinclination to work denotes a moral bankruptcy that justifies punitive action - the social problem novelists add a third term: luck. As already observed, they propose no alternative to the means of economic production, merely a call for a fairer distribution of outcomes and opportunities. But if market forces have to work in the manner suggested by political economy then the role played by good and bad luck in human affairs must surely be more considerable than allowed for by political economists and immorality must therefore be accorded less importance. There is a capriciousness on where, when and upon whom the axe falls. [example?] Our novelists therefore challenge political economy to be more consistent than hitherto.

But once luck has been added there is nonetheless a strong focus upon willingness to work (Sanders, 2003: 128-35) - see above. In David Copperfield self-discipline is that which transcends social background to mark men and women out as worthy or unworthy, by contrast in Great Expectations Pip is morally hollow until his fortune depletes and, like David, is forced to work his way towards becoming a true gentleman. It is the willingness to work rather than the desire to acquire riches that is important here. Fagin's gang are in their own way skilled workers but are 
nevertheless condemnable because they concentrate upon the end and not the means of work. Indeed, social problem novelists sometimes appear quite radical in their inclination to attack the idle rich as much as the idle poor. [Example?] So once again what we have here is a tendency to apply commonplace assumptions more consistently rather than develop an alternative set of political ethics. So long as affluence is deserved there is no condemnation of over-affluence or sense that poverty may be to some extent caused by this.

Nor, then, is there any attempt to recreate the moral economy of free time. Dickens et al certainly welcomed legislation to reduce working hours but there is no support for the early labour movement's resistance to the capitalist labour market per se. The social problem novels depict struggles over time in which free time becomes leisure, a recuperation from work during which the material and/or the familial rewards of working hard can be enjoyed, and is no longer an operating principle of a social economy. This is, after all, the period during which bank holidays and the modern notion of Christmas were introduced - Dickens being instrumental for the latter. The labouring body is therefore accepted as given and used as a means of unifying the classes by relocating moral worth upon willingness to work rather than upon inheritance, since the latter is a matter of luck and so arbitrary from a moral point of view. If willingness is the real platform of social status then this represents a kind of egalitarian justice in which the precise nature of the work matters less than its performance, the divisions between employer and employed fade and a conduit for a fairer distribution of the social product constructed.

So while the workhouse is damned the deserving/undeserving distinction is if anything perpetuated: the workhouses (and the debtors' prison) were inhumane constructions upon foundations that were ethically legitimate. If anything, they condemned the former because, by stirring up political militancy, they might ultimately undermine the latter. The novelists' hostility to trade unionism and Chartism perhaps stemmed from a fear that they would tear everything down, the ethical foundations as well as the institutions that political economists had foolishly assembled.

\section{Gender}

These ethical foundations are also viewed in gendered terms. Gallagher (1985: Ch.7) observes how Victorians appealed to the supposed virtues of the private sphere in order to compensate for the conflicts and vices of the public one. But the sanitised model of the home that this prompted only confirmed the gulf between public and private that social paternalists had wished to overcome. By emptying the domestic sphere of public struggles they only succeed in sublimating those struggles, not in addressing them. In Hard Times, for instance, the family unity achieved by the Gradgrinds at the novel's end only serves to betray the metaphorical coalition Dickens had earlier drawn between the Gradgrind children and the working class. By constructing a family ideal Dickens abdicates from public responsibility.

So it is women who are expected to carry the family ideal, to symbolise the domestic haven that offers retreat from public burdens. It has frequently been noted how dichotomised female characters in Victorian literature are $(* * * *)$. On one level we have the kind of angelic figure that reaches some kind of absurd height with Sybil, a figure upon whom Disraeli loads spiritual significance, but which is also visible in Margaret Hale, a realistic because flawed character who nevertheless provides North and South with its moral orientation. By contrast those who fail to embody this 
angelic ideal are shown in various states of falling from grace. There are the harmless but hopeless characters, such as Dora whom Dickens must kill off so that David Copperfield can marry his version of the womanly ideal. But there are also those who have crossed over a line beyond which no return is possible. Esther's descent into prostitution is suspended long enough for her to warn Mary Barton of inviting the same fate but Esther herself is not allowed to survive. In Bleak House Mrs Jellyby's philanthropy is inseparable from her inabilities as a mother, conveying the message that proper concern for others springs from a familial attachment to the immediate and the particular. That real charity is an extension of maternal instinct and feminine emotion is clear in the final image of Mrs Jellyby as having quickly become as obsessed with women's political rights as she had previously been with Africa. This comical portrait dilutes what may be Dickens's fear of women when unconfined. In Madame Defarge he portrays someone who has become so detached from the domestic that her maternal instincts bring destruction.

The work performed by women is therefore rendered indistinct, even as the deserving/undeserving distinction is upheld. Women are almost always employed in jobs assumed to be extensions of the natural role, i.e. as governesses, tutors or housekeepers, and then either as a temporary prelude to marriage or as a spinsterish alternative. It is only in such jobs that social problem novelists can envisage women, of which there are few examples anyway, reconciling employment and mothering; those women (like Mrs Jellyby) who have professional aspirations are rendered ridiculous. So whereas in men undeservingness is signified by a lack of willingness to work, in women it derives from a malfunctioning of the maternal instinct. All women are assumed to be carers but when they, either wilfully or ignorantly, care too little, too much or for the wrong thing they are set against the angelic ideal.

Poovey (1989: 10) therefore argues that gender was the site upon which virtue was rearticulated during this period. Where aristocratic feudalism had made class location central to its social and moral relations, the bourgeoisie had to pursue a more individualistic course. Virtue was depoliticised by being associated with a domestic sphere now perceived as being detached from the public, economic one. The middleclass homemaker comes to represent the ideal of morality and emotion. Economic reform is therefore depicted either as irrelevant to society's moral order, or even as inimical to it whenever radicals talk of altering property rights. The bourgeois family is therefore a goal to which all men and women, whatever their class, can and should strive. The gendered nature of early Victorian novels, e.g. the appeal to sentiment, is therefore a means of occluding class conflict and political struggle. Economic issues are quelled through the domestication of desire. The social world that lies behind the occasional appearance of illegitimate children, e.g. Smike in Nicholas Nickleby, is only ever alluded to since the direct depiction of middle class men going in search of sexual fulfilment among working class women might reveal the prevalence of class exploitation $(* * * *)$. So the psychological insights provided by Gaskell are a means by which domestic harmony is elevated over public turmoil and the emotional over the political; her heroines are only allowed to intervene in a society where the psychological is being disembedded from its social relations (Poovey, 1995: 143-52). If it took feminists a century to rediscover the political within the private it was partly because Victorian novelists had helped to dissociate politics from the domestic (Gilbert \& Gubar, 2000).

What these three strands add up to is a discourse familiar from political sociology and social policy alike: the simultaneous association and detachment of production, 
distribution and reproduction. Social problem novelists not only do not envisage significant alternatives to free market capitalism they close down the spaces (of class and collective action) through which such alternatives could be imagined. Their solution to the poverty that appalled them was therefore cooperation and fairer distribution within a framework of economic production that was essentially unalterable. Fairness was not to be determined according to precepts of justice, since this smacked of the kind of statistical abstraction they abhorred, but by constructing a community (Christian, national, familial) with which the reader was implored to identify and trusting to an intuitive, empathetic sense of right and wrong. Production and distribution are therefore disconnected from one another even as they are being associated. Economic and material circumstances are invoked as part of the problem but not as part of the solution since this might further threaten the communal fabric, the social interdependencies, which they regarded as buffers against the twin assaults of Utilitarian social engineering and laissez faire capitalism.

And as we have just seen the same process of association and disconnection is visible in their treatment of the family and of gender. The family is held to provide the utopian redemptions of which the public, political world is no longer capable. Women must therefore be located upon a spectrum constructed to maintain this familial ideal with angels at one extreme and devils at the other. Prostitution and sexual abuse are only ever alluded to very indirectly since otherwise this might highlight male exploitation and collapse the domestic ramparts that Victorian society was determined to sustain. And where these are dealt with, e.g. Esther, it is with reference to agent-centred failures of morality (denoting a lack of desert) that are detached from issues of economic and material circumstance. So, like production and distribution, reproduction is presented as a sphere-unto-itself, occupying the same imaginative space as the others but without being conceptually or politically integrated.

What the social problem novels therefore offer is a gradually deepening awareness of social interdependency. While in his early novels Dickens employs coincidence as an inept deus ex machina, by the latter books it becomes a logical consequence of the substratum he sees underpinning the teeming variety of social life and upon which the reader is allowed a glimpse, however partial and incomplete. This interdependency is partly an imaginative recreation of traditions other than political economy - Humean conservatism, romanticism and Carlylean idealism - but also a recognition of the linkages that industrial urbanisation was forcing upon humanity. The novelists' hope was that these linkages could be transformed from negative forms, e.g. disease, into positive forms of communal empathy. So while they were able to write about production (economic change and work), distribution (poverty and deprivation) and reproduction (home and family) they were suspicious of attempts to integrate these. Since the integrations promoted by Utilitarians and laissez faire advocates appeared undesirable they closed off the possibility of leftist integrations through class struggle. A single, integrative model of society was an unrealistic distortion of human complexity in that it seemed to make redundant those qualitative dimensions that cannot be modelled, e.g. need for empathetic understanding and communal respect. This discourse of welfare might therefore be termed the conjunctive non-integration of the spheres of production, distribution and reproduction, or what might otherwise be called the trisecting of society into three sectors. It will be the task of later stages of this project to see how this discourse evolved, and was itself challenged, as UK social policies developed. 


\section{The Ethics of Organic Individualism}

There are many respects, then, in which social problem novelists are counterhegemonic to political economics. They are concerned to look poverty squarely in the face and not theorise it away as contemporaries like Harriet Martineau had done. They grope towards some notion of fairness and dignity, not by offering abstract models of society or principles of justice, but by portraying human empathy as more virtuous than selfishness. Fair distribution is held to require the mutual recognition of others within some kind of moral community, so that the sphere of production does not require radical changes and can be conceived of as separate to that of distribution. Chartism and trade unions do not receive a sympathetic reception, therefore. There is an idealistic aspect to their vision (Cazamian, 1973): a suspicion of industrialism, reaching an extreme in the medievalism of Disraeli, articulated by the Carlyle's fear not only that society is becoming more dependent upon impersonal mechanisation but that humanity is taking on the qualities of a machine. There is also a resistance to the cash-nexus, to the idea that everything can and should be priced, since the novelist's eye sees within the human character depths to which quantitative scales cannot penetrate. So while recognising the materiality of social life materialism is rejected, whether this be the materialism of political economists or of political radicals who, in their obsession with wages and strikes, are held to have adapted the tenets of political economy rather than propounding a true alternative. Humans are not the manipulable beings that both sides hold them to be. They are not the components that can be endlessly substituted for one another in the blueprints of Utilitarian social engineers, nor the infinitely flexible atoms imagined by laissez faire thinkers, nor the surplus units that Malthusians imagine can be disposed of without social disruption; nor are they simply the bearers of their class positions. Instead, humans are portrayed as never fully distinct, as evading even the novelist's attempt to pin them down. In what is a highly modern conception, human identity is never complete because of the mutualist webs of interdependency out of which identities are constantly being reshaped as processes. This is why it is fiction which expresses something that government reports, statistical surveys and ideological formulae can never match: the pursuit of something that can never be caught because it is the pursuit itself which is important. Poverty is immoral not because it violates an egalitarian ideal but because it introduces into this codependent community divisions and misunderstandings that are neither inevitable nor desirable. Hierarchies within this community are acceptable because they need not, of themselves, prevent people from taking responsibility for others, of respecting others or of caring paternalistically for others. In a truly moral order distinctions between governors/governed and employers/employee do not equate to that of superior/inferior. Ultimately, what social problem novelists offer is a set of values that would recoordinate the ethical self-image of industrial capitalism.

But in reacting to the materialism of political economy, so by detaching values from their material context, these novelists are also content to leave the practices and relations of industrial capitalism more or less intact. For once there is mutual respect and recognition of the worth of others then how higher or lower those others are in terms of income, property and wealth matters far less. Competitive self-interest is not objectionable in itself, only its potential to descend into selfishness, one which a strong moral order is required to avoid. As already noted, this is why work is so vital. Whether you are a crossing-sweeper or factory-owner the dignity of work, its badge as a sign of social membership, of the willingness to recognise and be recognised, exists on another level that radical prescriptions divert us from. It is because not 
everyone can be a factory-owner that makes admission of essential human worth so vital. The workplace may be offensive but the work ethic is not. Nor is there any substantial hostility to the essentials of free markets for it is political and commercial institutions that are lacking and institutions are no more individuals interacting with other individuals. Social problem novels, then, are means of encouraging people to behave better towards one another. So while interdependencies are acknowledged theirs is still a reading that traces social origins back to the motivations, values, beliefs and actions of individuals. Interdependency is firmly rooted on and around individuals and not what later theorists would call social structures. Theirs is what might be called an organic individualism rather than something which is either fully social or holistic. Human characteristics may have been formed by the social environment but, through efforts of will, we are able to develop beyond our environments and remould them. Those who fail to do so are guilty of moral weakness rather than being the victims of material circumstance. As already observed, the family ideal is crucial to this conception and suggests why the sphere of reproduction is kept separate from that of production and distribution.

So if there are some respects in which social problem novelists are counterhegemonic there are others in which they are hegemonic and enable work-centred individualism to consolidate even if their understanding of social interaction is far more subtle and complex than the political economists'. This may be because, although influenced by romanticism and idealism also, they were arguably reaching back for earlier, conservative traditions of public benevolence that were in many respects the source for political economics as well. Our novelists are therefore constructing another version of this earlier tradition that goes at right angles to political economy rather than evading it entirely. For both they and the political economists they disdained bypass the moral economy that continued to inspire many within the labour movement throughout the nineteenth century.

\section{Conclusion}

I have inferred from a limited though influential series of books a particular view of society (as trisected) and a set of ethical coordinates (organic individualism) that exhibit hegemonic and counter-hegemonic features vis-à-vis classical political economics. I am not claiming that this reading is definitive of the authors in question since I have been concerned to think about their work in respect of a neglected area of study, social policy. Nor am I claiming that their stance is a microcosm from which early Victorian responses to social change can be easily generalised. Cultural discourses are obviously far more varied than that. Instead I have wanted to kick-start a programme of analysis by identifying one possible strand in post-1834 reactions to welfare reform, to construct an hypothesis that may or may not throw light upon the history of UK social policy and may or may not enable us to think through the connections between this subject and sociocultural studies. 